\title{
The Piercing of the Corporate Veil Doctrine: A Comparative Approach to the Piercing of the Corporate Veil in European Union and Albania
}

\author{
Albana Karapanço \\ Insurance Industry, Lawyer \\ Email: albana.karapanco@yahoo.com \\ Ina Karapanço \\ Banking Industry, Economist \\ Email: inakarapanco@gmail.com
}

Doi:10.5901/ajis.2013.v2n9p153

\begin{abstract}
Present research paper is focused on the piercing of the corporate veil in the European Union (EU) company law (CL) and Albanian CL. Considering the importance of corporate activity in our days, it is of a specific significance to discuss the applied standards whether the corporate veil should be pierced or not. The corporate veil doctrine presents one of the issues most studied in CL; the doctrine itself is closely related to two legal concepts such as legal personality of the corporate and limited liability of the people behind the corporate. Although limited liability of the corporate is defined by the $C L$ and even in the statute of the corporate, it is not uncontroverted. Along with that, courts examine different factors and conditions while decide to pierce the corporate veil. Company term is given in article (art.) 54 of the Treaty on the Functioning of the European Union (TFEU), as an art. which refers the constitution of the companies under specified legislation. In addition, the corporate is one of the most common business organisation that provides for its shareholders limited liability to the amount they have subscribed. Besides the theories and attempts form a comprehensive framework for piercing of the corporate veil, the decision is up to the court's discretion. The interpretation will be mainly based on the EU primary and secondary law, the doctrine for piercing the corporate veil, case laws and different articles; additionally one has to bear in mind that despite the metaphoric meaning, the veil dividing the corporate and people behind it may be set aside for the protection of higher interests.
\end{abstract}

Keywords: piercing the corporate veil, company law, doctrine, shareholders' liability, legal personality, primary and secondary law,

\section{Introduction}

This paper consists of five chapters. Subject of the first chapter is a brief summary of the concept of the legal personality and explains the definition of company and corporate. While considering the significance of this legal concept, the debate for the accepted separate legal personality of the corporate and the presumption of the entity as an artificial person and the arguments for piercing the veil take a particular importance. The second chapter clarifies the piercing of the corporate veil in the EU, by considering the procedure as a tool to remedy the abuse of shareholders or managers with the corporate. Also, for comparison reasons there are mentioned judicial practices of some EU states in the third chapter, followed by the piercing of the veil doctrine in Albania in the fourth chapter. The last chapter gives the objectives of the corporate veil doctrine, such as punishment, deterrence, compensation and avoiding unjust enrichment, used at the same time as courts' arguments to explain the decision to pierce or not the corporate veil.

Based on this approach, present paper will show a critical review of the piercing of the corporate veil doctrine.

\section{Company's Legal Personality}

The core idea of the $\mathrm{CL}$ is the legal personality of the company. In a wide legal meaning the company is an entity incorporated under the respective company act of a state. The company or other legal forms are mechanisms which carry on many types of activity; the corporate form is the legal form available across so many types and sizes of activity. The simplest explanation to understand the concept of the corporate personality is that the corporation is a legal entity distinct from its members. Though, the corporate is considered an artificial person capable of entering into contract as a party, owning property, and being claimant or defendant in legal proceedings. The direction and control of a business 
enterprise, organised in a limited liability corporate is known as corporate governance. Meanwhile, the concept of the legal personality and limited liability are strictly related to one another. In addition, Council Regulation (EC) No. 2157/2001 defines the framework on the statute for a European Company. The act foresees that the liability of shareholder is limited to the amount he has subscribed (Council Regulation (EC) No. 2157/2001, 08.10.2001, on the Statute for a European Company (SE), Official Journal, L 294/1, 10.11.2001, art. 1, paragraph 2) and an Societas Europaea (SE) shall have legal personality (Ibidem, paragraph 3). Although, art. 9 provides the hierarchy of acts governing the SE; the regulation itself, the SE statute when is expressively authorised by the regulation or Member States' (MS) laws as specified (Ibidem, art. 9, paragraph 1).

In reference to art. 54 of the TFEU, companies or firms means companies or firms constituted under civil or commercial law, including cooperative societies, and other legal persons governed by public or private law (Consolidated Version of the TFEU, Official Journal, C 83/4730.03.2010, art. 54, paragraph 2). Directive 2006/46/EC states in its preamble that the bodies of the company act within the competences assigned to them by national law, but it is not prevented for MS to provide direct responsibility towards shareholders or stakeholders and it is not precluded the ability of courts or other enforcement bodies in the MS to impose penalties on an individual board member (Directive 2006/46/EC of the European Parliament and the Council of 14 June 2006 Official Journal, L224/1, 16.08.2006, preamble, paragraph 2). By one hand, the separate legal personality of the corporate is crucial for its creation and existence, and by the other hand it is accepted the limited liability of every natural person and/or other legal entity that may influence the corporate activity; thus it should always be considered the risk of abuse of the corporate governance and to whom goes the liability.

\section{Piercing of the Corporate Veil Doctrine}

Observing the literature for this doctrine, it is noticed that it is not simple to find the origins of piercing the corporate veil. This is perhaps because the practice has shown that it has never been simple to define if the limited liability of the natural persons in a legal entity is absolute or not.

On my opinion the $\mathrm{CL}$ of the state provides the provisions for piercing the corporate veil but there are two important questions to be answered; what the scope of the law is and how the law is applied. Despite the provisions may be a matter of interpretation, the $\mathrm{CL}$ has to be clear and reduce the most possible the metaphoric meaning of piercing the corporate veil. Initially, the CL has to clarify explicitly all the duties and responsibilities of shareholders, members and administrators and should state the causal link between the actions and the consequences that bring the piercing of the corporate veil.

Therefore, the analysis of the piercing of the corporate veil concerns two aspects. The first one relates to what is meant by this term and the second one relates to the explanation when the veil is lifted. While studying the doctrine of the separate legal personality of the corporate one of the most typical cases is the Salomon case. Firstly, this case established that a company will be validly incorporated, even if it is only a one person company and secondly, the courts will be reluctant to treat a shareholder as personally liable for the debts of the company by piercing the corporate veil (Davies, L.P., Principles of Modern Company Law, Sweet and Maxwell Ltd, (2008), Eight Edition, 35). Following the statement of the House of Lords, the English Court of Appeal imposed personal liability on Mr. Salomon for the debts of his company. The piercing of the corporate veil expresses the court decision to impose personal liability on the shareholders, director or officers of the corporate. It seems there is a slight veil dividing the corporate from the people behind the corporate.

Piercing the corporate veil is a common law legal doctrine through which shareholders are held accountable by considering the corporate action as it was the shareholders' own (Matheson, J.H., Why Courts Pierce: An Empirical Study of Piercing the Corporate Veil, Berkeley Business Law Journal, Vol. 7, 2010, 4). The court is the institution which decides whether or not to pierce the corporate veil and it is crucial to understand why courts decide to pierce or not to pierce the corporate veil.

However, in the doctrine of the piercing of the veil corporation there are always different features which should be considered. One question raised is if the piercing happens more often when the owners of the corporate are individuals or the owner is an entity. The close relation between a parent corporation and its subsidiary may lead to the abuse of the administrative or financial control of the first entity over the second one. Another question is if the piercing happens with the same frequency whether the plaintiff is a corporate entity or an individual. Above all, one should bear in mind; the court may pierce even in the presence of only one factor if it is considered enough to pierce (Ibidem 9). Though, during the process of examination the court evaluate even the type of company, the reasons why the company was established, the legal action occurred and identify the person who ask for the piercing of the veil. 
One of the first judgments in the piercing of the corporate veil doctrine is the case Belgium v. Spain on the Barcelona Traction, Light and Power Company, Limited. Barcelona Traction Light and Power Company, Limited was a company incorporated in Canada and controlled light and powers utility in Spain. Most of the shareholders of the company were Belgium nationals. Due to the bankruptcy proceeding in Spain, Belgium brought a claim against Spain on behalf of its nationals. The International Court of Justice (ICJ) provided in its judgment that an act infringing only the company's rights did not involve responsibility towards the shareholders, even if their interests were affected (ICJ, Case Belgium v. Spain, the Barcelona Traction, Light and Power Company Limited, Judgment of 05.02.1970, second phase, 77).

In different circumstances and for different reasons there are distinguished four different attitudes of the courts towards the company (Ottolenghi, S., From Peeping Behind the Corporate Veil, to Ignoring it Completely, Modern Law Review, Vol. 53, 1990, 340). The first category is peeping behind the veil; the purpose is only to get information involving the persons who control the company and their inter-relation with regard to the control of the company (Ibidem). The second category is penetrating the veil; the purpose is to impose upon the shareholders responsibility for the company's acts or to establish their direct interest in the company's assets (Ibidem, 343). The third category is the extension of the veil; the purpose is to extent the veil over a group of entities carrying out common activities and to consider them as a single one (Ibidem, 347). The fourth category presents the most extreme attitude by ignoring completely the corporate veil (Ibidem, 351).

The doctrine of alter ego is commonly used in the United States (US). The doctrine requires the presence of two elements together before piercing the corporate veil. The first element requires the unity of interest and ownership between the corporation and its equitable owner; as a result the company and shareholder do not represent separate personalities. The second element requires that the inequitable result comes as a result of the act of the company owner who hides behind the corporate form (McCloskey, D.T., Alter Ego: Piercing the Corporate Veil, California Lawyer, 2008, 42).

\section{Piercing the Corporate Veil in European Union}

All jurisdictions offer doctrinal tools for holding shareholders liable for the debts of the companies, although, the use of these tools is restricted to controlling or managing shareholders who are found to have abused the corporate form (Kanda Hideki, Davies Paul, Hopt Klaus J. and Kraakman Reinier, The Anatomy of Corporate Law: A Comparative and Functional Approach, Oxford University Press, Second Edition, 2009, 138). Piercing the corporate veil is one of these tools. The $C L$ of different states has different approaches on veil-piercing.

For comparative illustrating purposes there will be given cases of several EU states relating to the piercing of the corporate veil. All jurisdictions in EU permit courts to pierce the corporate veil in extreme circumstances, in order to hold controlling shareholders or the controllers of corporate groups personally liable for the company's debts. Achieving this, the courts do not set aside the corporate form easily (Bainbridge Stephen M., Abolishing Veil Piercing, Journal of Corporation Law 26, 2001, 479).

In EU jurisdictions, for instance, the veil piercing is permitted when the controlling shareholders disregard the integrity of their companies by failing to take care of formalities, intermingling personal and company assets with each other, or failing to capitalise the company adequately. Here can be mentioned the case Adams v. Cape Industries, 1990 in the United Kingdom (UK). Moreover, veil piercing is as well applied when there is an element of fraud or injustice, as when shareholders have clearly behaved opportunistically (Kanda Hideki, Davies Paul, Hopt Klaus J. and Kraakman Reinier, The Anatomy of Corporate Law: A Comparative and Functional Approach, Oxford University Press, Second Edition, 2009, 138). In France, for example, insolvency procedures can be extended to shareholders that disregard the integrity of their companies (Commercial Code of France, art. 621 paragraph 2, art. 631 paragraph 7, art. 641 paragraph 1). Therefore, the piercing of the corporate veil can be considered as performing the function to imposing liability on a shareholder.

Piercing of the corporate veil doctrines in the EU are occasionally used to protect creditors of corporate groups. Here, it is applied the same as in US jurisdictions, which follow the doctrine of substantive consolidation which gives the bankruptcy courts the power to put assets and liabilities of two related corporations into the same table (Mevorach Irit, The Appropriate Treatment of Corporate Groups in Insolvency, European Business Organisation Law Review 8, 2007, 179). In the jurisprudence has been noted that veil piercing is no more common within groups of companies than it is between companies and controlling shareholders who are individuals (Thompson Robert B., Piercing the Corporate Veil: An Empirical Study, Cornell Law Review 76, 1991, 1056). The last mentioned is the same as in the US, where the courts 
pierce the veil in more than forty percent of the decided cases to reach the assets of individual shareholders, and in more than thirty-five percent of decided cases to reach the assets of corporate shareholders.

However, it is created a supplementary set of creditor protection standards which cover groups of companies in some jurisdictions in the EU, constituting a special law of corporate groups. The typical case is Germany, which provides the most elaborated example of such a law, attempting to balance the interests of groups as a whole with those of the creditors and minority shareholders of their individual members. It is of interest to mention the situation when the creditors of the subsidiary branch may sue the parent's directors for damages (Emmerich Volker and Haserback Mathias, Konzernrecht, Eighth Edition, 2005, paragraph 302, paragraph 309, 446-447). In this case, if the parent company has not entered into a contract of domination, it must compensate any subsidiaries that it causes to act contrary to the subsidiary's own interests (The same approach has been adopted in Italy. For further see: art. 2497, Italian Civil Code, para. 2, under which the controlled firms must disclose the effect of dominance on company management and results).

Apart from their national juridical law and practice in several EU countries relating to piercing the corporate veil, are noticed several cases in EU level to this doctrine. When it comes to pierce the veil of a single company it is easier. The situation becomes delicate when there are several of them, depending on one another. In a recent decision, Akzo Nobel $N V$ v. Commission, the European Court of Justice (ECJ) affirmed a line of previous cases, including Stora Koppabergs Bergslags AB v. Commission (C-286/98, Stora Kopparbergslags AB v. Commission, 2000, E.C.R. I-9925, paragraph 20), which held that complete share ownership establishes a presumption that the parent exercises control over the subsidiary (C-97/08, Azko Nobel NV v. Commission, 2009, E.C.R. 1-8237, paragraphs 55, 58-62). According to this, the parent company and the subsidiary companies will be treated as a single economic entity (Ibidem, 60-61). The same stands for the case Michelin v. Commission, where the European Court of First Instance emphasised that the "Community competition law recognises that different companies belonging to the same group form an economic unit and therefore an undertaking." (C-T203/01 Michelin v. Commission, 2003, E.C.R. II-4071, paragraph 290). The same is echoed in Akzo Nobel NV v. Commission, where the ECJ reaffirmed that a parent and its subsidiary must be understood and considered as a sole economic unit even if in law that economic unit consists of several persons, natural or legal (C-97/08, Azko Nobel NV v. Commission, 2009, E.C.R. I-8237, paragraph 55). The latest decision is in full accordance with the arts. 101 and 102 of TFEU.

Aiming to introduce the corporate veil complex doctrine in different countries, other than EU, is of interest to mention China. Here the notion of piercing the corporate veil did not exist formally prior to 2006 . The China $\mathrm{CL}$ is unclear about whether the factors stated by its $\mathrm{CL}$ are the only factors that courts consider, or alternatively, whether courts may consider additional factors when adjudicating a demand to pierce the corporate veil (Wu Mark, Piercing China's Corporate Veil: Open Questions from the New Company Law, The Yale Law Journal, 2007, 330). Meanwhile, the AngloAmerican system does not require fraud as a necessary precondition, under the French system a plaintiff must show that a corporation committed one of three types of fraud before courts will pierce the corporate veil (Ibidem). German courts and US courts have adopted a list of factors to be taken in consideration to decide on veil-piercing (Ibidem).

However, it is of importance to mention that under EU approach, firstly, a shared ownership establishes rebuttable presumption that the parent exercises control over the subsidiary. The burden then falls on the parent to demonstrate that the subsidiary possesses commercial autonomy. In the UK such presumption does not exist in the single economic unit theory (In Gramaphone and Typewriter v. Stanley, the notion that complete share ownership of a subsidiary confers control over the parent was specifically rejected). Secondly, under the EU law, not only does the parent become liable for the subsidiary's fine, moreover, parent company's revenue will also be taken into account for the calculation of the fine.'

In other words, the EU approach not only shifts liability, but it actually expands it. As a result, the limited liability of companies weakens, whereas the liability of the group increases.'

\section{Piercing of the Corporate Veil in Albania}

The piercing of the corporate veil in the Albanian Legislation may be viewed in the framework of several laws. The Stabilisation and Association Agreement (SAA) requires that the Albanian companies, the same as the European companies, be incorporated and perform their activity in equal basis (Stabilisation and Association Agreement between EU Member States and Albania, art.50 paragraphs 1, 3). Despite of the approximation of legislation, the Law "On Entrepreneurs and Companies" attempts to protect the creditors. Thus, this Law ("On Entrepreneurs and Companies", No. 9901, date 14 April 2008 (amended), art. 16. paragraph 1) has foreseen the exceptions from the principle of the limited liability. Company members and shareholders, administrators and members of the Board of Administration are jointly and severally liable for the company commitments to the extent of their total assets in three cases. 
Firstly, they are held responsible if they abuse the company form for illegal purposes; thus it is required the element of fraud on the part of the person who acts or fails to act as required. Secondly, they are held responsible if they treat the company assets as if they were their own assets. Thirdly, they are held responsible if they fail once they know or must have known of the company's inability to pay his debts and they shall ensure the company has sufficient capital to meet its commitments. In addition, the provision requires the intention to the result. The third cause may be problematic to correlate to a specific situation because the words "must have known" and "sufficient capital" maybe subject to a wide interpretation. Also, other provisions of the $\mathrm{CL}$ render the administrator liable to compensate the company for any damage caused by the violation of his duties and the standard of diligence (Ibidem, art. 98, paragraph 3 and art. 163 paragraph 3).

The Law "On Bankruptcy" has provided the condition when members or shareholders of the company are held personally liable and punished with a fine (Law "On Bankruptcy", No. 8901, date 23 May 2002 (amended), art. 16, paragraphs 1, 2). According to these provisions, the members and shareholders of the company shall initiate the bankruptcy procedures since they become aware of the insolvency activity of the company. If they do not initiate the procedure by submitting the request to the court, up to the period of three months after they are aware of the insolvency, they will be personally liable. In this context, one should analyses two sides of the problematic. On one hand, it should be considered if the provision is sufficient to justify the piercing of the corporate veil; on the other hand, the provision should be interpreted to justify only the liability of the members and shareholders of the company for the failure to initiate the bankruptcy procedure.

The Law "On Tax Procedures" states that even after the sale of the seized assets of the company, the tax liability is not fully paid; it is transferred as a liability of the shareholder or administrator (Law "On Tax Procedures" No. 9920, date 19.05.2008 (amended), art. 99). Unlikely, the Law "On Bankruptcy", this provision refers to the art. 16 of the Law "On Entrepreneurs and Companies". What art. 99 of Law "On Tax Procedures" states is valid also in cases when at the end of the liquidation or bankruptcy process, the tax liability of company is still unpaid.

As a result, the principle of piercing the corporate veil is part of the Albanian legislation. The above mentioned laws are enacted or amended in the same period of time which explains a correlated logic between them. These laws refer different subjects as personally responsible for the liabilities of the companies to third parties but no one of them explains explicitly the connection from the actions of the persons to be held liable to the consequences and the extent of liability. Therefore, the court has the discretion to decide when piercing the corporation veil; the court decides the insolvency of the company, the intentional element of the shareholders or members of the company and sets aside the limited liability of the company. Through interpretation, may be concluded that the court has the role to observe and decide when and why the veil should be pierced.

\section{Objectives of the Corporate Veil Doctrine}

Corporate veil doctrine does not definitely address the question of what its main objective is, because given the variety of corporate veil cases, it is impossible to arrive at a single objective that considers all the cases. However, veil-piercing is an equitable procedure that involves the creation of liability in spite of the contractual and statutory separateness of corporate entities (Cheng Thomas K., Form and Substance of the Doctrine of Piercing the Corporate Veil, Mississippi Law Journal, Volume 80, 2010, 526). Nevertheless, it needs to be emphasised that the corporate veil doctrine does not expand the liability imposed on the corporation. This doctrine just ensures that liability is met to the fullest extent possible (The extent to which liability will be paid in full also depends on the amount of shareholder assets. In a way. every liability is limited in the sense that it is subject to the possibility of the corporate). It merely transposes the liability, to the extent that it is not fulfilled after the corporate assets have been exhausted, from the corporation to the defendant shareholder (Ibidem). Therefore, the doctrine does not change the size of the liability; it concentrates the entire liability on one or a few culpable shareholders.

There are several objectives of the corporate veil-piercing doctrine, however, the most important to mention are punishment, deterrence, compensation and avoiding unjust enrichment. Considering punishment, this can happen in some of the inadequate capitalisation cases identified by the court, when the defendant company is subject to a liability that significantly exceeded the shortfall in capitalisation. The defendant shareholder can be said to have been punished for his failure to capitalise the corporation adequately. According to this objective, though rarely used, it is necessary to punish and deter companies intentionally engaged in reprehensible conducts, and stop them from behaving or conducting their unjust activities in the future. The corporate veil doctrine performs a compensatory function. In particular, it helps to restore the full compensatory effects of the underlying contractual or tort damages that otherwise would have been curtailed by limited liability (Cheng Thomas K., Form and Substance of the Doctrine of Piercing the Corporate Veil, 
Mississippi Law Journal, Volume 80, 2010, 530).'A company by the operation of the limited liability rule would have confined maximum recovery to the sum of the corporation's assets. To the extent that the main function of the contractual and tort liabilities is compensatory (Shavell Steven, Foundations of Economic Analysis of Law, Belknap Press of Harvard University Press, 2004, 177-256), the corporate veil doctrine preserves this function.

'Deterrence is another possible objective of the veil piercing. According to the doctrine, the types of conduct that qualify as improper conduct include fraud, circumvention of a statutory prohibition, misrepresentations, torts and other cases of wrong or injustice. Examination of the possible deterrent effects of the corporate veil doctrine requires a more nuanced understanding of how liability creates deterrence and how this inducement works in the context of the corporate veil doctrine (Cheng Thomas K., Form and Substance of the Doctrine of Piercing the Corporate Veil, Mississippi Law Journal, Volume $80,2010,535$ ). For the law to have a deterrent effect on undesirable conduct, the penalty must be greater than the benefits the defendant obtains from such conduct (Shavell Steven, Foundations of Economic Analysis of Law, Belknap Press of Harvard University Press, 2004, 211). Otherwise, the defendant would be always willing to take a chance with the hope that the conduct will not be detected. The question of how the corporate veil doctrine achieves deterrence needs to be analysed differently for intentional improper conduct and non-intentional or probabilistic improper conduct such as negligence-based torts.'

A principal objective of the corporate veil piercing doctrine is the prevention of unjust enrichment and restitution of the shareholders (Sherwin Emily, Restitution and Equity: An Analysis of the Principle of Unjust Enrichment, Global Studies Law, Review 2, 2001, 208-209). This is one of the reasons why the court's repeated assertion that the corporate veil piercing doctrine is ultimately about preventing injustices. This principle allows the courts to create individualised exceptions to general legal rules and also describes the role of the corporate veil doctrine as a standard based exception to the general rule of limited liability.

\section{Conclusion}

The doctrine of the piercing of the corporate veil presents one of the most debated subjects in company law since the beginning of the twentieth century. The doctrine involves the choice between the legal certainty and the achievement of justice in several cases. Whenever discussing the piercing of the corporate veil, there are included the legal personality of the corporate and the limited liability of its shareholders. Although, there is no clear definition when the veil should be pierced or not, courts have decided case by case. By taking in consideration a number of factors in regard to the corporate, shareholders, and the pretender, the courts decide if the interest infringed may justify the pierce of the corporate veil.

In my opinion, the procedure to pierce the corporate veil is a matter of interpretation of the court; the court has the discretion to evaluate which is the highest interest that should be protected. Meanwhile the court decision should explain the reasons for setting aside the legal personality and making the shareholders or people behind the corporate responsible for the corporate debts. It cannot be considered easy to break what is legally established and known, such as legal personality and limited liability.

In this regard, the decision to pierce or not the corporate veil is the result of balancing all features of the case. In general there are four objectives of the corporate veil doctrine, such as punishment, deterrence, compensation and avoiding unjust enrichment. These objectives aim to stop company's misconduct or unfair activities.

In addition, all jurisdictions in EU permit courts to pierce the corporate veil in extreme circumstances, in order to hold controlling shareholders or the controllers of corporate groups personally liable for the company's debts. The judicial practice throughout the countries in EU has significant similarities with the judicial practices followed in UK and US.

Additionally in Albania the laws refer different subjects as personally responsible for the liabilities of the companies to third parties but no one of them explains explicitly the connection from the actions of the persons to be held liable to the consequences and the extent of liability. Therefore, the court has the discretion to decide when piercing the corporation veil and has the role to observe when and why the veil should be pierced.

All of these practices regarding the piercing of the veil in companies look like as they are becoming more compact and consolidated as well as similar with each other.

\section{References}

\section{Court Decisions}

C-286/98, Stora Kopparbergslags AB v. Commission, 2000, E.C.R. I-9925 
C-T203/01 Michelin v. Commission, 2003, E.C.R. II-4071

C-97/08, Azko Nobel NV v. Commission, 2009, E.C.R. I-8237

Case Belgium v. Spain, International Court of Justice, the Barcelona Traction, Light and Power Company, Limited, Judgment of 05.02.1970

\section{Journals}

Bainbridge Stephen M., Abolishing Veil Piercing, Journal of Corporation Law 26, 2001

Cheng Thomas K., Form and Substance of the Doctrine of Piercing the Corporate Veil, Mississippi Law Journal, Volume 80, 2010

Matheson, J.H., Why Courts Pierce: An Empirical Study of Piercing the Corporate Veil, Berkeley Business Law Journal, Vol. 7, 2010

Mevorach Irit, The Appropriate Treatment of Corporate Groups in Insolvency, European Business Organisation Law Review 8, 2007

Ottolenghi, S., From Peeping Behind the Corporate Veil, to Ignoring it Completely, Modern Law Review, Vol. 53, 1990

Sherwin Emily, Restitution and Equity: An Analysis of the Principle of Unjust Enrichment, Global Studies Law Review 2, 2001

Thompson Robert B., Piercing the Corporate Veil: An Empirical Study, Cornell Law Review 76, 1991

\section{Legislation}

Commercial Code of France

Consolidated Version of the Treaty on the Functioning of the European Union, 2010

Council Regulation (EC) No. 2157/2001, 08.10.2001, on the Statute for a European Company (SE), Official Journal, L 294/1, 10.11.2001

Directive 2006/46/EC of the European Parliament and the Council of 14 June 2006

Law "On Entrepreneurs and Companies", No. 9901, date 14 April 2008 amended

Law "On Bankruptcy", No. 8901, date 23 May 2002 amended

Law " On Tax Procedures" No. 9920, date 19.05.2008 amended

Stabilisation and Association Agreement between EU Member States and Albania

\section{Monographies}

Davies, L.P., Principles of Modern Company Law, Sweet and Maxwell Ltd, Eight Edition, 2008

Emmerich Volker and Haserback Mathias, Konzernrecht, Eighth Edition, 2005

Kanda Hideki, Davies Paul, Hopt Klaus J. and Kraakman Reinier, The Anatomy of Corporate Law: A Comparative and Functional Approach, Oxford University Press, Second Edition, 2009

McCloskey, D.T., Alter Ego: Piercing the Corporate Veil, California Lawyer, 2008

Shavell Steven, Foundations of Economic Analysis of Law, Belknap Press of Harvard University Press, 2004 